\title{
†Carlomonnius quasigobius gen. et sp. nov.: the first gobioid fish from the Eocene of Monte Bolca, Italy
}

\author{
ALEXANDRE F. BANNIKOV \& GIORGIO CARNEVALE
}

\begin{abstract}
The first gobioid fish from the Eocene of Monte Bolca, Italy, $\uparrow$ Carlomonnius quasigobius gen. et sp. nov., is described based on a single well-preserved diminutive specimen. This taxon is the oldest member of the Gobioidei known to date based on articulated skeletal remains. $\dagger$ Carlomonnius gen. nov. exhibits a suite of features that unquestionably support its alignment with gobioids, including the absence of parietals and basisphenoid, possession of a large and subquadrangular saccular otolith, infraorbital series exclusively represented by the lachrymal, presence of suspensorial interspace, caudal skeleton with reduced parhypural and fused hypurals $1+2$ and $3+4$ (the latter fused to the urostyle), absence of uroneurals, absence of supraneurals, presence of cleithral notch, and absence of lateral line. Within the Gobioidei, $\uparrow$ Carlomonnius gen. nov. has a unique combination of derived (five branchiostegal rays, dorsal postcleithrum absent, 13 principal caudal-fin rays, four pelvic-fin rays) and plesiomorphic (dorsal fin continuous, 24 vertebrae, autogenous haemal spine of the second preural centrum, first two abdominal centra shortened, first dorsal-fin pterygiophore inserting in the second interneural space) features found in none of the extant gobioid lineages. Because of this unique combination of features, $†$ Carlomonnius gen. nov. cannot be confidently accommodated within any familial category and it is therefore interpreted herein as incertae sedis within the Gobioidei. Palaeoecological considerations suggest that $\dagger$ Carlomonnius quasigobius gen. et sp. nov. was a benthic generalist carnivore. - Key words: Teleostei, Gobiiformes, Gobioidei incertae sedis, †Carlomonnius quasigobius gen. et sp. nov., Eocene, Monte Bolca, Italy.
\end{abstract}

BAnNiKov, A.F. \& CARneVAlE, G. 2016. $\dagger$ Carlomonnius quasigobius gen. et sp. nov.: the first gobioid fish from the Eocene of Monte Bolca, Italy. Bulletin of Geosciences 91(1), 13-22 (3 figures). Czech Geological Survey, Prague. ISSN 1214-1119. Manuscript received July 16, 2015; accepted in revised form September 4, 2015; published online December 2, 2015; issued March 17, 2016.

Alexandre F. Bannikov, Borisyak Paleontological Institute, Russian Academy of Sciences, Profsoyuznaya 123, 117997 Moscow, Russia • Giorgio Carnevale (corresponding author), Dipartimento di Scienze della Terra, Università degli Studi di Torino, Via Valperga Caluso, 35 I-10125 Torino, Italia; giorgio.carnevale@unito.it

The early Eocene marine fishes from Monte Bolca in northern Italy have been known since the mid-sixteenth century for their extraordinary preservation. The first comprehensive monographic work on these fishes, the "Ittiolitologia Veronese", was published by the Abbot G.S. Volta in 1796. Some years later, Agassiz (1833-1844) published his monumental palaeoichthyological milestone, "Recherches sur les Poissons Fossiles", which was largely based on material from Monte Bolca. Since that time a remarkable number of papers have been devoted to the Monte Bolca fish fauna, based on the thousands of specimens extracted from this locality and now disseminated in museums and research institutes around the world. The majority of the fossil fishes from Monte Bolca have been extracted from the celebrated Pesciara cave site. The most recent censuses of the Monte Bolca fish diversity (Bannikov 2014, Carne- vale et al. 2014) recognized 238 taxa, 222 of which are actinopterygians. The fish fauna is strongly dominated by acanthomorphs (not less than 190 species), with a diversity foreshadowing that of today (Patterson 1993). Undoubtedly, such amazing palaeoichthyological diversity will be increased by future investigations. There are still several newly recognized taxa awaiting description, and some known taxa or lineages are badly in need of revision. Monte Bolca marks the first fossil record of many groups of teleost fishes, including those associated with modern coral reefs (e.g., Bellwood 1996, Carnevale et al. 2014). However, some groups of fishes currently extremely abundant in reef biotopes (e.g., butterflyfishes and gobies) have not yet been documented from the Monte Bolca assemblage, where they were represented instead by extinct ecological analogues (Bannikov 2004a, b). 
Up to now, gobioid fishes appear to be represented at Monte Bolca by a single highly questionable record (Bannikov 2014). Agassiz (1833-1844) described $\dagger$ Gobius microcephalus Agassiz, 1839 based on a single specimen of a small fish in the collection of Dr. Hartmann (Goeppingen). Woodward (1901, p. 588) indicated the "typical" specimen of $\dagger$ Gobius microcephalus as part of the collection of the Natural History Museum, London (NHMUK 44873), whereas Blot (1980) considered the type specimen as being present in the collection of the $\mathrm{Mu}$ seum National d'Histoire Naturelle, Paris (MNHN 11067/11068, currently MNHN Bol 422/Bol 423). Eastman (1905, pl. II, fig. 3) figured the MNHN specimen and documented the differences with the specimen originally described by Agassiz. Both specimens NHMUK 44873 and MNHN Bol 422/Bol 423, although almost equally small in size, are not identical to the specimen figured by Agassiz (1833-1844, pl. 34, fig. 2) and therefore none of them can be regarded as the holotype of $\dagger$ Gobius microcephalus. However, it seems likely that all of them belong to the same taxon, of which additional specimens are present in the MNHN collection (Bol 430/Bol 432) and many others are part of the extensive collection of the Museo Civico di Storia Naturale, Verona (MCSNV). Among the other shared features, all of them exhibit a single dorsal fin and three supraneurals, thereby implying that they cannot be regarded as belonging to the gobioid clade. A revision of the material currently referred to as "†Gobius" microcephalus Agassiz is within the schedule of our continuing investigations of the Monte Bolca fish fauna.

The goal of this paper is to describe what appears to be a diminutive gobioid fish from Monte Bolca recently found among the undescribed material in the fossil fish collection of the MCSNV. The Gobioidei is one of the most speciose groups within percomorphs, comprising more than 2000 species (see Nelson 2006) arranged into eight families, the Butidae, Eleotridae, Gobiidae, Gobionellidae, Milyeringidae, Odontobutidae, Rhyacichthyidae, and Thalasseleotridae (e.g., Thacker 2009, Chakrabarty 2010, Gill \& Mooi 2012, Agorreta et al. 2013). Despite such an impressive present diversity, the early phases of their evolutionary history are unclear, mostly because of the scarcity of their fossil record. Molecular studies suggest that gobioids diverged from other gobiiforms late in the Cretaceous (e.g., Near et al. 2013), even if the earliest occurrence of the group consists of rare otoliths from the middle Ypresian shallow marine deposits of the Vastan Lignite Mine, Gujarat, India (Nolf et al. 2006), stratigraphically corresponding to the lower part of the SBZ 10 (Punekar \& Saraswati 2010), with a minimum age of about $55 \mathrm{Ma}$. At present, the skeletal record of the group dates back to early Lutetian deposits of the Vallfogona Formation, exposed near Borredà, Barcelona
Province, Spain (Gaudant 1996), with a minimum age of about $45 \mathrm{Ma}$. As a consequence, the new gobioid from Monte Bolca described herein represents the earliest skeletal record for this highly diverse and heterogeneous percomorph lineage.

\section{Material and methods}

The specimen documented herein was found among the undescribed material collected during the latest excavations conducted at the Pesciara cave site and housed in the MCSNV. The fossil consists of a relatively well-preserved complete articulated skeleton preserved on the surface of inframillimetrically laminated micritic limestone. Some details of the specimen examined were best seen when the specimen was moistened with alcohol. The specimen was examined using a Leica M80 stereomicroscope equipped with a camera lucida drawing arm and measurements were taken with a dial caliper to the nearest $0.1 \mathrm{~mm}$. Standard length (SL) is used throughout. The spinous dorsal-fin pterygiophore formula follows Birdsong (1975) and Birdsong et al. (1988). All extinct taxa are marked with daggers ( $\dagger$ ) preceding their names.

\section{Systematic palaeontology}

Division Percomorphacea Wiley \& Johnson, 2010

Order Gobiiformes Günther, 1880

Suborder Gobioidei Jordan \& Evermann, 1896

\section{Genus †Carlomonnius gen. nov.}

Type species. - †Carlomonnius quasigobius sp. nov.

Etymology. - After the Italian actor and poet Carlo Monni.

Diagnosis. - A diminutive gobioid fish with body moderately elongate and caudal peduncle relatively elongate; head relatively large; jaws with pointed and slightly recurved conical teeth; five branchiostegal rays; vertebral column containing $24(10+14)$ vertebrae; haemal spine of the second preural centrum autogenous; dorsal pterygiophore formula 2-3111; dorsal fin notched and continuous, with seven slender flexible spines and 11 rays; short-based anal fin with a single spine and 7 rays; three anterior anal-fin pterygiophores inserted anterior to first haemal spine; pelvic fin with a single spine and four segmented rays; pelvic fins anterior to pectorals; ventral postcleithrum present; caudal fin rounded with $13(7+6)$ principal rays; body covered with thin cycloid scales.

Composition. - Type species only. 

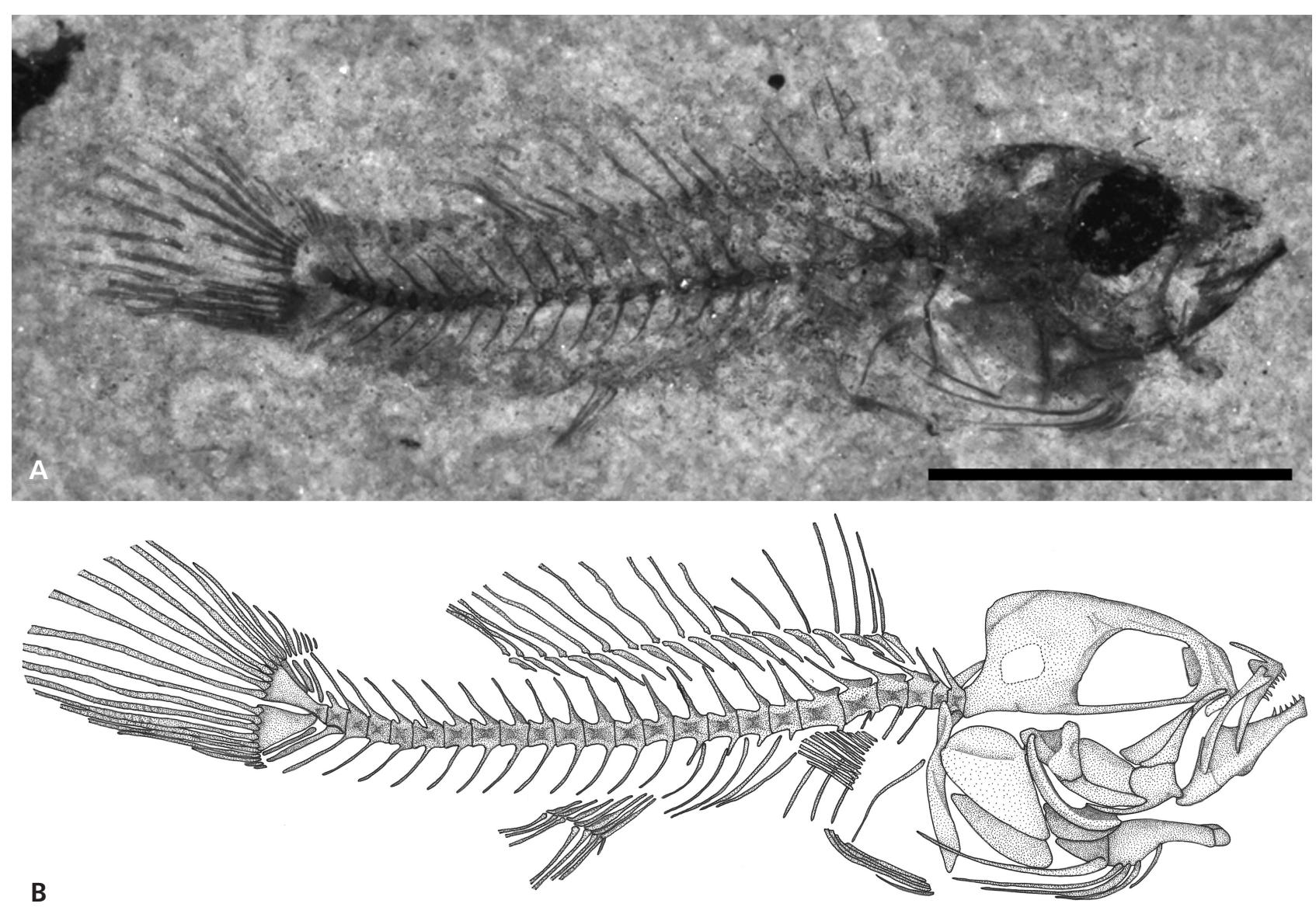

Figure 1. $\dagger$ Carlomonnius quasigobius gen. et sp. nov., from the Eocene of Monte Bolca, Italy. • A - holotype, MCSNV IGVR71187, right lateral view, scale bar $5 \mathrm{~mm}$. $\bullet$ B - interpretative reconstruction of the skeleton based on MCSNV IGVR71187, right lateral view.

\section{$\dagger$ Carlomonnius quasigobius sp. nov.}

Figures 1-3

Holotype. - MCSNV IGVR71187, well-preserved complete articulated skeleton in a single plate, $13 \mathrm{~mm} \mathrm{SL}$ (Fig. 1A).

Referred specimens. - None.

Type locality and horizon. - Monte Bolca locality, Pesciara cave site; Early Eocene, late Ypresian, middle Cuisian, SBZ 11, Alveolina dainelli Zone, about 50 Ma (see Papazzoni et al. 2014).

Diagnosis. - As for the genus.

Etymology. - The name is derived from the Latin quasi, meaning "as if" or "just like"; and the gobioid genus Gobius.

Measurements. - As percentage of SL: head length: 35; maximum body depth: 29; snout length: 8 ; orbit diameter:
11.9; mandible length: 15.6; caudal peduncle depth: 12.5 ; predorsal length: 38.7; predorsal (soft dorsal) length: 54.4; preanal length: 67.8; prepelvic length: 40.3; dorsal-fin base length: 37; spinous dorsal-fin base length: 13.1; soft dorsal-fin base length: 21.9; anal-fin base length: 6.6; longest dorsal-fin spine length: 12.2; last dorsal-fin spine length: 2.8; longest dorsal-fin ray length: 13.1; longest anal-fin ray length: 8.1 ; longest caudal-fin ray length: 24.4.

Description. - The body is relatively elongate, with a moderately deep and elongate caudal peduncle (Fig. 1). The caudal peduncle depth is contained slightly more than two times in maximum body depth. The body reaches its maximum depth at the level of the occiput. The head is relatively large and somewhat depressed; its length exceeds the body depth. The head length (HL) is contained 2.8-2.9 times in SL. The dorsal and ventral profiles of the body are almost equally gently convex.

The head is moderately deep, with its depth about 1.2 times less than its length. The orbit is relatively large and placed in the upper half of the head. The eyeball is preserved as a thin carbon film. The horizontal diameter of the 


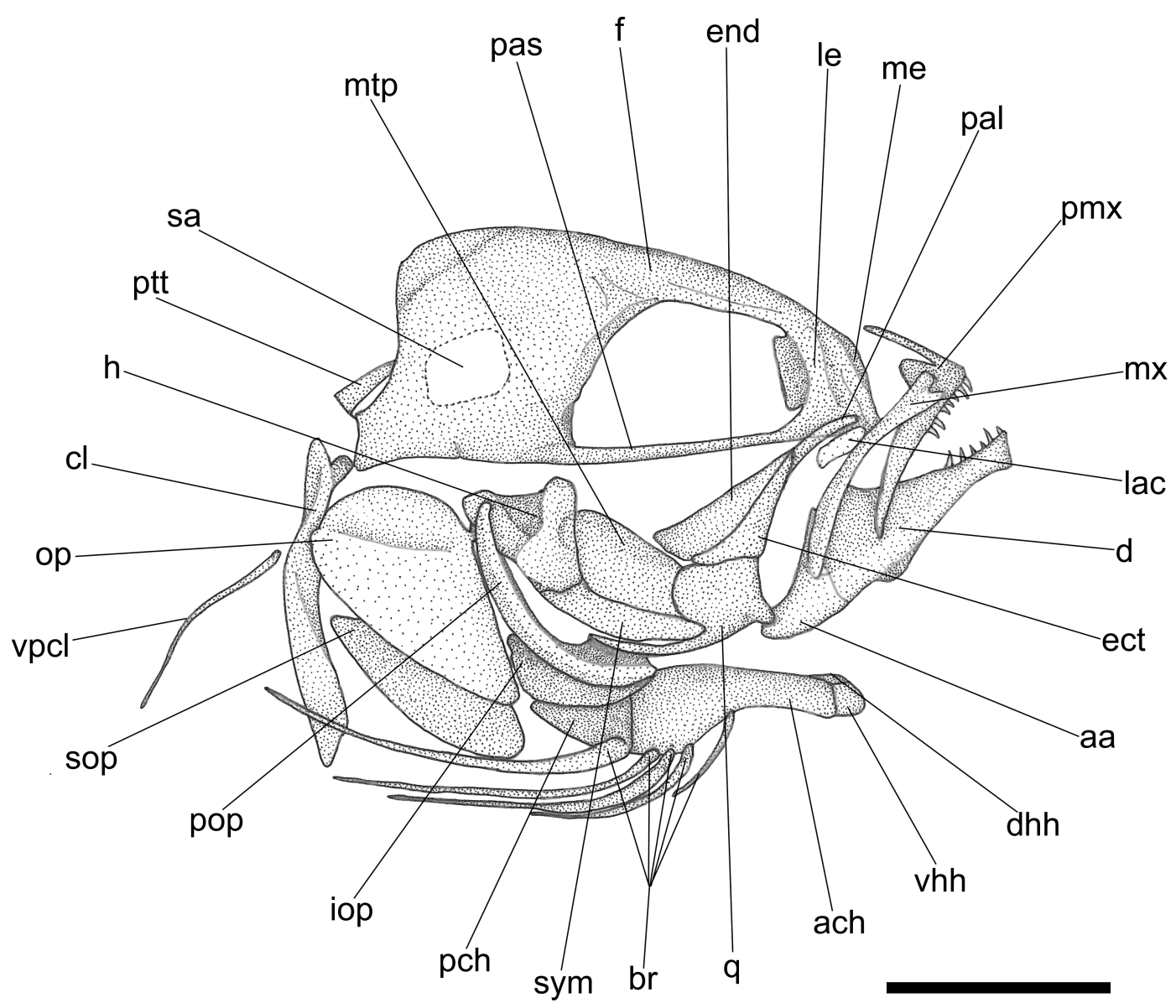

Figure 2. †Carlomonnius quasigobius gen. et sp. nov., reconstruction of the head and pectoral girdle. Scale bar $1 \mathrm{~mm}$. Abbreviations: aa - angulo-articular; ach - anterior ceratohyal; br - branchiostegal rays; cl - cleithrum; d - dentary; ect - ectopterygoid; end - endopterygoid; dhh - dorsal hypohyal; f - frontal; h - hyomandibula; iop - interopercle; lac - lachrymal; le - lateral ethmoid; me - mesethmoid; mtp - metapterygoid; mx - maxilla; op - opercle; pal - palatine; pas - parasphenoid; pch - posterior ceratohyal; pmx - premaxilla; pop - preopercle; ptt - posttemporal; q - quadrate; sa - saccular otolith (sagitta); sop - subopercle; sym - symplectic; vhh - ventral hypohyal; vpcl - ventral postcleithrum.

orbit is about $34 \% \mathrm{HL}$. The snout is rather short; its length is about $23 \% \mathrm{HL}$. The mouth is relatively small and terminal. The lower jaw articulation is situated below the anteriormost border of the orbit.

The neurocranium is moderately deep, with the supraoccipital crest evidently not developed (Fig. 2). The frontals are the largest bones of the skull roof; each of these bones bears a supraorbital latero-sensory canal. There is no evidence of parietals. The ethmoid region is moderately developed. The vomer appears to be toothless. The mesethmoid bears a thin bony lamina that projects posteriorly forming a short anterior septum between the orbits. The lateral ethmoid is columnar and forms most of the anterior wall of the orbit. The parasphenoid is slender and almost straight. The basisphenoid is clearly absent. The bones of the otic and occipital portions of the neurocranium are difficult to interpret because of inadequate preservation. However, the external profile of a large and approximately quadrangular saccular otolith (sagitta) can be recognized in the otic sector of the neurocranium.
The infraorbital series is represented by a single small and subrectangular bone (lachrymal) placed close to the ventrolateral corner of the lateral ethmoid (Fig. 2).

The premaxilla has well-developed and separate ascending and articular processes. There are some preserved premaxillary teeth apparently arranged into a single row; these are sharp and conical, with recurved tips. The maxilla is curved, anteriorly forked and not significantly expanded distally. There is no evidence of the presence of a supramaxilla. The lower jaw is relatively low; its length is about $48 \%$ HL. The lower jaw dentition is similar to that of the upper jaw (Fig. 2). A small and low flange with gently curved profile emerges along the ventral margin of the dentary. There is no evident gap between the dorsal processes of the dentary and angulo-articular. The angulo-articular has a moderately developed coronoid process.

The suspensorium and associated opercular complex appears to be detached from the neurocranium, displaced from its original position possibly due to post-mortem 
Figure 3. †Carlomonnius quasigobius gen. et sp. nov., reconstruction of the caudal skeleton. Scale bar $1 \mathrm{~mm}$. Abbreviations: ep - epural; hpu2 - haemal spine of the second preural vertebra; hyp hypural; npu2 - neural spine of the second preural vertebra; phy - parhypural; $\mathrm{pu}$ - preural centrum; $\mathrm{u}$ - ural centrum.

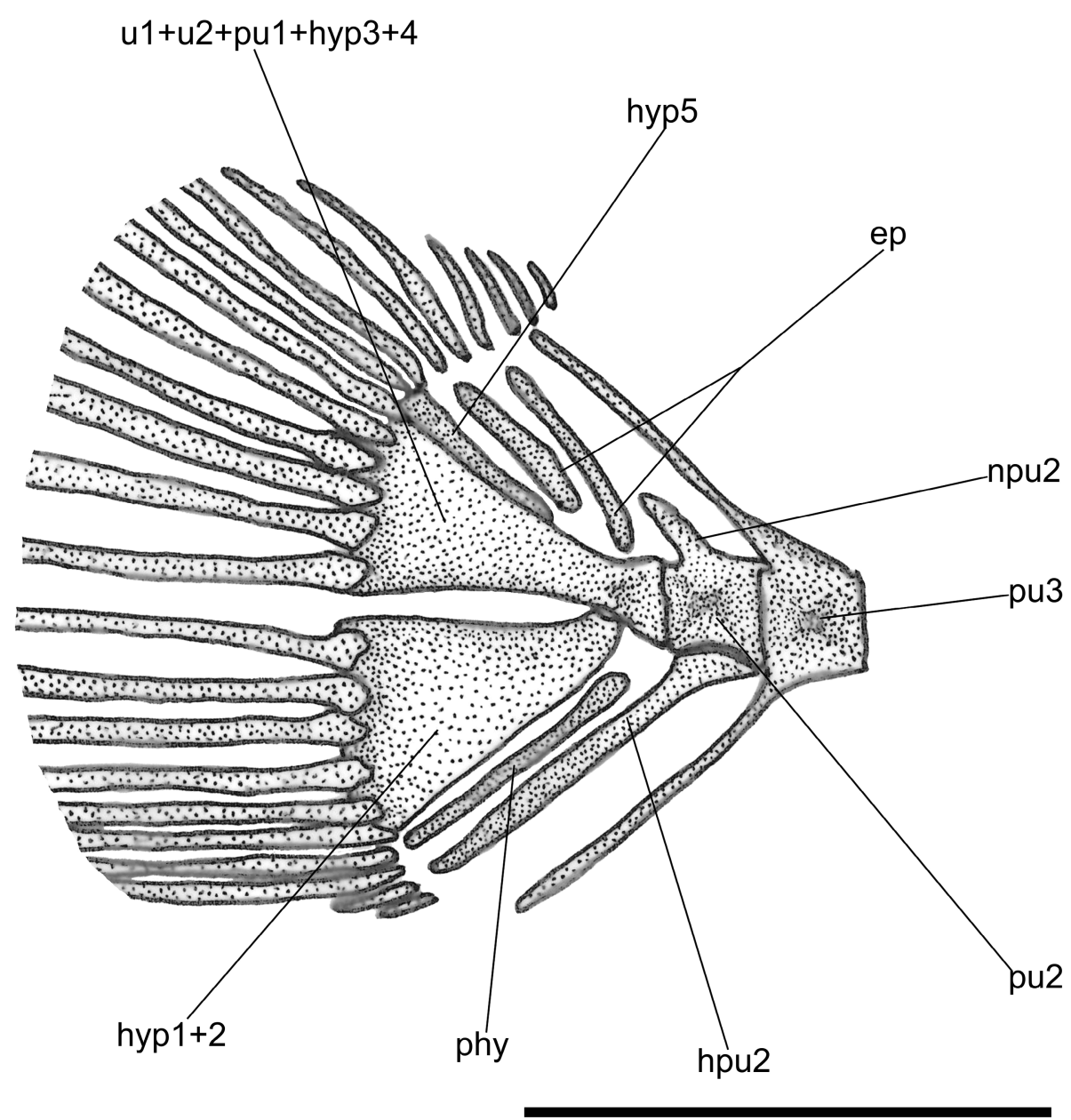

taphonomic processes (Fig. 1B). The suspensorial bones are clearly recognizable (Fig. 2). The hyomandibula consists of an irregular plate with two robust dorsal articular facets and a remarkably reduced ventral arm; the opercular process is very short. The hyomandibula articulates ventrally with a notably large and slightly curved symplectic and anteriorly with a subrectangular metapterygoid. The symplectic and preopercle are not in contact with each other, thereby producing a moderately developed unossified suspensorial interspace (see Harrison 1989). The quadrate is massive and irregular in outline. The ectopterygoid is thin and elongate, with a roughly triangular outline. The endopterygoid is well developed. The palatine is relatively short; the morphology of the anterior end of the palatine is difficult to interpret.

The preopercle is crescent-shaped, bearing a thin flange along its anteroventral margin; this an anteriorly projecting flange articulates with the posterior margin of the quadrate (Fig. 2). The interopercle is laminar and characterized by a rounded ventral profile. The opercle is broad, nearly triangular in outline, with a convex dorsal profile; this bone has a thickened anterior border and a robust horizontal ridge arising from the concave condyle, which articulates with the opercular process of the hyomandibula. The subopercle is flat and relatively elongate.

The hyoid bar is robust (Fig. 2). The anterior ceratohyal is remarkably expanded posteriorly. The posterior ceratohyal is nearly triangular in outline. Both dorsal and ventral hypohyals can be recognized. There are five branchiostegal rays; the anteriormost ray is slender and short; the last four rays are long and sabre-like (Fig. 2). The first branchiostegal ray articulates with the ventral margin of the narrow part of the anterior ceratohyal, the next three articulate with the ventral margin of the expanded part of the anterior ceratohyal, and the fifth articulates with the lateral surface of the posterior ceratohyal.

The bones of the branchial skeleton cannot be recognized in the single available specimen.

The vertebral column comprises $24(10+14)$ vertebrae, including the urostyle (Fig. 1B). The axis of the vertebral column is slightly curved. Except for the two anteriormost vertebral centra, the centra are subrectangular in outline and longer than high. The centra of the two anteriormost vertebrae are approximately quadrate in outline and evidently shorter than those of the succeeding vertebrae. The length of the caudal portion of the vertebral column is 
about 1.4 times greater than the length of the abdominal portion. The neural spines are straight or slightly curved and slender. Parapophyses of gradually increasing size are recognizable in the seven posterior abdominal vertebrae. The pleural ribs are slender and moderately long. Fragments of epineurals can also be recognized.

The terminal urostylar vertebra is formed by the fusion of the first preural and two ural centra with the hypurals $3+4$ (Fig. 3). Hypurals $1+2$ are fused in a single plate. The fifth hypural is scarcely preserved. The parhypural and haemal spine of the second preural vertebra are autogenous; the proximal region of the parhypural is separated by a moderately developed gap from the urostylar vertebra (Fig. 3). There are no uroneurals. The neural spine of second preural centrum is short and pointed. The neural and haemal spines of the third preural vertebra are somewhat longer and stronger than those of the preceding vertebra. Two epurals appear to be present. The caudal fin is relatively large, with a distinctly rounded profile. The caudal fin comprises $13(7+6)$ principal rays plus seven dorsal and four ventral procurrent rays (Figs 1B, 3).

There are no supraneurals (Fig. 1B). The dorsal fin is moderately elongate and continuous; it originates at the level of the fourth vertebra and terminates over the $16^{\text {th }}$ vertebra. It comprises seven dorsal-fin spines plus 11 distally segmented rays, supported by 17 pterygiophores. The dorsal-fin spines are extremely slender and flexible. The two anteriormost dorsal-fin spines are closely associated to each other; the subsequent dorsal-fin spines are more widely spaced. The spines gradually increase in length from the first to the third; the length of the succeeding spines gradually decreases posteriorly. The first dorsal-fin spine is supernumerary on the first dorsal-fin pterygiophore. The longest dorsal-fin rays are situated in the middle of the soft dorsal fin. The longest soft ray of the dorsal fin is longer than the longest dorsal-fin spine. The length of the base of the soft portion of the dorsal fin is 1.7 times longer than that of the spiny portion. The three anteriormost pterygiophores insert in the second interneural space. The dorsal pterygiophore formula (see Birdsong et al. 1988) is 2-3111. The third to $14^{\text {th }}$ dorsal-fin pterygiophore have a primarily one-to-one relationship with the underlying vertebrae; the proximal shafts of the ninth and tenth and $15^{\text {th }}$ and $16^{\text {th }}$ pterygiophores lie in the eighth and $13^{\text {th }}$ interneural spaces, respectively. There are no vacant interneural spaces.

The anal fin is very short and only moderately preserved (Fig. 1B); it originates under the third caudal vertebra and terminates under the level of the posterior margin of the fifth caudal vertebra. The anal fin comprises seven segmented rays preceded by a short spine; these are supported by seven slender pterygiophores. The insertion of the three anterior pterygiophores appears to be positioned in advance of the first haemal spine. The anal-fin spine is in supernumerary association on the first pterygiophore. The anal-fin pterygiophores seem to not enter into the overlying interhaemal spaces, terminating below the lower tips of the haemal spines.

The pectoral girdle is only partially preserved (Fig. 2). Some of the bones of the pectoral girdle are not preserved at all, suggesting that these were probably cartilaginous or, alternatively, not fully ossified in this specimen. What appears to be the dorsal arm of the posttemporal is preserved in front of the neural spine of the first abdominal vertebra. The supracleithrum is not preserved at all. The cleithrum is elongate and crescent-shaped with a moderately expanded ventral portion. The dorsal end of the cleithrum is bifid and characterized by a relatively deep notch, the so-called cleithral notch, through which Baudelot's ligament would have passed (see Winterbottom 1993). The articular process for the pelvic girdle is not exposed, and is probably fully developed along the medial side of the cleithrum. The dorsal postcleithrum appears to be absent; the ventral postcleithrum is well ossified, curved and rib-like. The scapula, coracoid and pectoral fin radials cannot be recognized. The base of the pectoral-fin of the holotype is situated under the fifth vertebra, close to the midpoint between the vertebral column and the ventral profile of the body. The size of the pectoral fins is unclear; the proximal parts of about 12 rays are preserved.

The basipterygium is not recognizable (Fig. 1). The pelvic fin is narrow and moderately elongate, suggesting that the two contralateral pelvic fins were not fused to each other. The pelvic fin comprises a slender spine and four soft segmented rays. The pelvic-fin insertion is located anterior to the pectoral-fin base (Fig. 1B).

Thin and large cycloid scales cover the entire body and head. There is no evidence of the lateral line.

Minute spots of dark pigment are regularly disseminated on the scales along the whole body length (Fig. 1A).

Discussion. - The taxonomic interpretation of fossil gobioid fishes is rather problematic, mostly because the systematics of the extant gobioids is largely based on the pattern of lateralis system sensory papillae and/or canal pore configuration (e.g., Sanzo 1911, Aurich 1938, Hoese 1983, Pezold 1993), all features that cannot be observed in fossil material. However, the limits of this structurally diverse and speciose group have been extensively discussed and several synapomorphies have been defined in the last four decades (e.g., Regan 1911, Miller 1973, Birdsong 1975, Springer 1983, Birdsong et al. 1988, Hoese \& Gill 1993, Johnson \& Brothers 1993, Winterbottom 1993, Wiley \& Johnson 2010). Some of these concern skeletal structures (e.g., caudal complex, neurocranium, suspensorium) that are usually exposed in fossils, whereas a few others refer to delicate osteological features (e.g., presence of pelvic intercleithral and ventral intercleithral cartilages; first basi- 
branchial cartilaginous; otolith primordia), to soft anatomy (e.g., sperm-duct glands) or to ontogeny (see Johnson \& Brothers 1993, Winterbottom 1993) and therefore are not useful for the interpretation of fossil material.

As evidenced in the descriptive analysis, the overall morphology, as well as several osteological features exhibited by $†$ Carlomonnius gen. nov. support its alignment with gobioid fishes. In particular, the absence of parietals and basisphenoid in the neurocranium, possession of a large and subquadrangular saccular otolith, infraorbital series reduced to a small lachrymal, presence of an open space between the greatly enlarged symplectic and preopercle (suspensorial interspace), caudal skeleton with reduced parhypural, fused hypurals $1+2$ and $3+4$ (the latter fused to the urostyle) and autogenous fifth hypural, absence of uroneurals, absence of supraneurals, presence of cleithral notch, and absence of lateral line unquestionably indicate that it is a member of the highly heterogeneous gobioid clade (e.g., Springer 1983, Johnson \& Brothers 1993, Winterbottom 1993, Wiley \& Johnson 2010). Moreover, like other gobioid taxa, †Carlomonnius gen. nov. possesses exceptionally slender and flexible dorsal-fin spines. Finally, most gobioids have two or more anal-fin pterygiophores inserting anterior to the first haemal spine (Birdsong at al. 1988), a condition also present in $\dagger$ Carlomonnius gen. nov., which has three pterygiophores in advance of the first haemal spine.

Due to the diminutive size of the fossil documented herein, the presence of certain osteological features potentially recognizable in well-preserved material (e.g., branchial skeleton) cannot be determined. For example, the significant space available between the pectoral-fin base and the cleithrum might suggest that the typical gobioid large pectoral radials were not fully ossified or completely cartilaginous in the single specimen of the new taxon (see Springer 1983).

Within gobioid fishes, $\uparrow$ Carlomonnius gen. nov. exhibits a unique suite of plesiomorphies and derived features that clearly separate it from the other members of this vast group.

Like almost all basal gobioids (rhyacichthyids, odontobutids, eleotrids and butids), †Carlomonnius gen. nov. has a well-developed endopterygoid (see Akihito 1969); this bone is absent in the suspensorium of thalasseleotrids, gobionellids, and gobiids (Gill \& Mooi 2012). The axial skeleton of the new Eocene gobioid in some respect appears to be more generalized than that of any gobioid. The dorsal-fin origin of $\dagger$ Carlomonnius gen. nov. is situated unusually anterior compared to that of other gobioids; the first dorsal-fin pterygiophore of gobioids usually enters the third interneural space, and sometimes even more posteriorly, while the anteriormost dorsal-fin pterygiophore of $\dagger$ Carlomonnius gen. nov. inserts in the second interneural space; within extant gobioids, such a condition has been observed only in some gobiids (Gunnellichthys and Paragunnellichthys; Birdsong et al. 1988). The first two vertebrae of $\dagger$ Carlomonnius gen. nov. are shorter than the succeeding elements, unlike in gobioids, in which the first centrum appears to be equal in length to the succeeding centra (Johnson \& Brothers 1993). The vertebral column of $\dagger$ Carlomonnius gen. nov. consists of 24 vertebrae, whereas the extant gobioids usually have more than 25 vertebrae (Birdsong et al. 1988); however, Birdsong et al. (1988) reported that such a primitive condition has been observed only occasionally in extant gobiids of the genus Eviota. Another very unusual feature of $\dagger$ Carlomonnius gen. nov. regards the structure of the caudal skeleton, in which the haemal spine of the second preural centrum appears to be autogenous, whereas it is fused to the centrum in all other gobioids (Monod 1968, Fujita 1990). It is worth noting that both the possession of 24 vertebrae, and the autogenous haemal spine of the second preural centrum, are currently regarded as representing the primitive condition in apogonids (Fraser 2013), the sister group of gobioid fishes (e.g., Thacker 2009, Agorreta et al. 2013).

As far as derived features are concerned, $\dagger$ Carlomonnius gen. nov. shares the possession of five branchiostegal rays with gobiids and gobionellids (see Thacker 2009); all other non-gobiid gobioids have six rays, the anteriormost two of which articulate with the ventral margin of the narrow part of the anterior ceratohyal (Hoese 1984, Hoese \& Gill 1993), while seven rays have been reported only in the extinct eleotrid genus $†$ Pirskenius (Obrhelová 1961, Přikryl 2014). As documented above, $\dagger$ Carlomonnius gen. nov. lacks a dorsal postcleithrum, a condition shared with thalasseleotrids, gobiids, and certain derived eleotrids (Springer 1983, 1988; Gill \& Mooi 2012). Evident reduction of the pelvic-fin rays to four in $\dagger$ Carlomonnius gen. nov. is similar to that typical of certain eleotrids, gobiids, and gobionellids (Hoese 1984). The primitive number of principal caudal-fin rays in gobioids is 17 (9+8), whereas the caudal fin of $\dagger$ Carlomonnius gen. nov. contains $13(7+6)$ principal rays, a derived condition that characterizes many gobiids and some eleotrids (Johnson \& Brothers 1993).

In summary, the comparative analysis of selected morphological and meristic features reveals that the affinities of $\dagger$ Carlomonnius gen. nov. within the Gobioidei are difficult to evaluate. It has a unique combination of derived [five branchiostegal rays, dorsal postcleithrum absent, $13(7+6)$ principal caudal-fin rays, four pelvic-fin rays] and plesiomorphic [e.g., dorsal fin continuous, 24 (10+14) vertebrae, autogenous haemal spine of the second preural centrum, first two abdominal centra shortened, first dorsal-fin pterygiophore inserting in the second interneural space] features found in none of the extant gobioid lineages, thereby suggesting that it cannot be confidently accommodated within any familial category. $\dagger$ Carlomonnius 
gen. nov. shares the possession of five branchiostegal rays and lack of dorsal postcleithrum with the derived families Gobiidae, Gobionellidae, and Thalasseleotridae. At the same time it exhibits the plesiomorphic condition of a vertebral column containing 24 vertebrae, and a second preural vertebra with an autogenous haemal spine. Such a complex mosaic of features makes it very complicated to interpret its affinities within this highly diverse and heterogeneous group of percomorph fishes, for which additional comparative information would be necessary. Therefore, because of the problematic identification of the sister-group relationships of †Carlomonnius gen. nov., we recommend that the classification of $\uparrow$ Carlomonnius gen. nov. should reflect such indeterminate relationships by placing it as incertae sedis within the Gobioidei.

\section{Concluding remarks}

$\dagger$ Carlomonnius quasigobius gen. et sp. nov. has a unique combination of morphological features that ensure its separate status within the speciose gobioid clade. As pointed out above, this late Ypresian marine fish is the earliest known gobioid based on articulated skeletal material. It is based on a single specimen measuring $13 \mathrm{~mm}$ SL. Despite its very small size, most of its skeleton is well developed and robust, suggesting that it represents at least a young adult individual; this hypothesis is also supported by the absence of any trace of a black abdominal peritoneum, which is a typical feature of fish larvae, and is usually preserved in fossils as a thin carbon film similar to that residue of the eyeball. The Gobioidei is a group characterized by numerous diminutive taxa, particularly among tropical species (Lachner \& Karnella 1980, Winterbottom \& Emery 1981, Winterbottom 1990), some of which are considered among the smallest living vertebrates (see Johnson $\&$ Brothers 1993). The existence of very small-sized fishes has been explained using a number of ecological hypotheses (Schoener 1974, Werner 1984, Marzluff \& Dial 1991, Munday \& Jones 1998). In general, small-sized fish species are able to exploit the fine-grain aspects of the environment, being more specialized in terms of habitat use than large species, particularly in the complex tropical shallow water biotopes. In these contexts, small-sized fish taxa usually occupy sheltered and restricted microhabitats not available to the larger species (see, e.g., Tyler 1971, Tyler \& Böhlke 1972, Patton 1994, Randall et al. 1997). As pointed out by Miller (1979), the broad variety of biotopes occupied by small-sized fishes reflects a wide distribution of potential living space and food organisms. The overall morphology of $†$ Carlomonnius quasigobius gen. et sp. nov. clearly suggests that it was a benthic fish. Based on their habitat use, small-sized benthic fish species may be classified as epibenthic or cryptobenthic (Miller 1979); unfortunately, this classification cannot be used unambiguously to define the palaeoecology of $\dagger$ Carlomonnius quasigobius gen. et sp. nov. Small-sized benthic fishes play a significant role in trophodynamics of tropical shallow water biotopes (e.g., Ackerman \& Bellwood 2002). The diet of these fishes is notably diverse, encompassing a full range of trophic food groups. Depczynski \& Bellwood (2003) found a clear relationship between diet and body length, with the taxa (or individuals) having a total length less than $30 \mathrm{~mm}$ being invariably carnivores and generalists; such a diet was likely characteristic of $\dagger$ Carlomonnius quasigobius gen. et sp. nov.

\section{Acknowledgments}

This paper is dedicated to the memory of Carlo Monni, an extraordinary actor and poet who died on May $19^{\text {th }} 2013$ (we really miss you!). We are particularly grateful to Giuseppe Minciotti, Director of the MCSNV, for providing funding for the travel of AFB in 2015 to Verona to engage in this and other studies. At the MCSNV we also thank Roberto Zorzin and Anna Vaccari for their continuing help in facilitating our research on the fishes from Monte Bolca, and Bruna Burato for her valuable bibliographic support. Thanks are also due to Marco Pavia (Dipartimento di Scienze della Terra, Università degli Studi di Torino) for the photographs, and to Federica Giudice for improvements of the English. We are grateful to Christine E. Thacker (Ichthyology, Natural History Museum of the Los Angeles County) for helpful comments on the manuscript. The manuscript was improved by the constructive review given by James C. Tyler (National Museum of Natural History, Smithsonian Institution, Washington) and Tomáš Přikryl (Institute of Geology, Academy of Sciences of the Czech Republic, Prague). The research of AFB was supported by the Russian Foundation for Basic Research, project No. 14-04-00005. The research of GC was supported by grants (ex-60\% 2013 and 2014) from the Università degli Studi di Torino. The names of the authors are in alphabetical order since each made a substantial contribution to this manuscript.

\section{References}

Ackerman, J.L. \& Bellwood, D.R. 2002. Comparative efficiency of clove oil vs rotenone for sampling tropical reef fish assemblages. Journal of Fish Biology 60, 893-901.

DOI 10.1111/j.1095-8649.2002.tb02416.x

Agassiz, L. 1833-1844. Recherches sur les Poissons Fossiles. Tomes I-V. 1420 pp. Petitpierre, Neuchâtel.

Agorreta, A., San Mauro, D., Schliewen, U., Van Tassell, J.L., KovaČIĆ, M., Zardoya, R. \& RÜBER, L. 2013. Molecular phylogenetics of Gobioidei and phylogenetic placement of European gobies. Molecular Phylogenetics and Evolution 69, 619-633. DOI 10.1016/j.ympev.2013.07.017

АкIніто, P. 1969. A systematic examination of the gobiid fishes 
based on the mesopterygoid, postcleithra, branchiostegals, pelvic fins, scapula and suborbital. Japanese Journal of Ichthyology 16, 93-114.

AuRICH, H.J. 1938. Die Gobiiden (Ordnung: Gobioidea). Internationale Revue der gesamten Hydrobiologie und Hydrographie 38, 125-183. DOI 10.1002/iroh.19390380106

BAnNiKov, A.F. 2004a. Eocottidae, a new family of perciform fishes (Teleostei) from the Eocene of northern Italy (Bolca). Studi e Ricerche sui Giacimenti Terziari di Bolca 10, 17-35.

BANNIKov, A.F. 2004b. Fishes from the Eocene of Bolca, northern Italy, previously classified with the Chaetodontidae (Perciformes). Studi e Ricerche sui Giacimenti Terziari di Bolca 10, 55-74.

BAnNikov, A.F. 2014. The systematic composition of the Eocene actinopterygian fish fauna from Monte Bolca, northern Italy, as known to date. Studi e Ricerche sui Giacimenti Terziari di Bolca 15, 23-33.

Bellwood, D.R. 1996. The Eocene fishes of Monte Bolca: the earliest coral reef fish assemblage. Coral Reefs 15, 11-19. DOI 10.1007/BF01626074

BIRDSONG, R.S. 1975. The osteology of Microgobium signatus Poey (Pisces: Gobiidae), with comments on other gobioid fishes. Bulletin of the Florida State Museum, Biological Sciences 19, 135-187.

Birdsong, R.S., Murdy, E.O. \& Pezold, F.L. 1988. A study of the vertebral column and median fin osteology in gobioid fishes with comments on gobioid relationships. Bulletin of Marine Science 42, 174-214.

BLOT, J. 1980. La faune ichthyologique des gisements du Monte Bolca (Province de Vérone, Italie). Catalogue systématique présentant l'état actuel des recherches concernant cette faune. Bulletin du Muséum national d'Histoire naturelle (Paris), sér. 4, section C 2(4), 339-396.

Carnevale, G., Bannikov, A.F., Marramà, G., Tyler, J.C. \& Zorzin, R. 2014. The Pesciara-Monte Postale FossilLagerstätte: 2. Fishes and other vertebrates, 37-63. In Papazzoni, C.A., Giusberti, L., Carnevale, G., Roghi, G., BAssi, D. \& Zorzin, R. (eds) The Bolca Fossil-Lagerstätten: A window into the Eocene World. Rendiconti della Società Paleontologica Italiana 4.

Chakrabarty, P. 2010. Status of Milyeringidae, with the description of a new blind cave fish from Australia, Milyeringa brooksi, n. sp. Zootaxa 2558, 19-28.

Depczynski, M. \& Bellwood, D.R. 2003. The role of cryptobenthic reef fish in coral reef trophodynamics. Marine Ecology Progress Series 256, 183-191. DOI 10.3354/meps 256183

Eastman, C.R. 1905. Les types de poissons fossiles du Monte-Bolca au Muséum d'Histoire Naturelle de Paris. Mémoires de la Société Géologique de France, Paléontologie 34, 3-32.

FrASER, T.H. 2013. A new genus of cardinalfish (Apogonidae: Percomorpha), redescription of Archamia and resemblances and relationships with Kurtus (Kurtidae: Percomorpha). Zootaxa 3714, 1-63. DOI 10.11646/zootaxa.3714.1.1

FujitA, K. 1990. The Caudal Skeleton of Teleostean Fishes. 897 pp. Tokai University Press, Tokyo.

Gaudant, J. 1996. Mise en évidence des plus anciens Gobioidei (Poissons téléostéens) connus dans le Lutétien inférieur de
Catalogne (Espagne). Comptes rendus de l'Académie des sciences, Série 2, Sciences de la terre et des planètes 322,71-76.

GiLl, A.C. \& MooI, R.D. 2012. Thalasseleotridae, new family of marine gobioid fishes from new Zealand and temperate Australia, with a revised definition of its sister taxon, the Gobiidae (Teleostei: Acanthomorpha). Zootaxa 3266, 41-52.

GüNTHER, A.C.L.G. 1880. An Introduction to the Study of Fishes. 720 pp. Adam and Charles Black, Edinburgh.

HARRISON, I.J. 1989. Specialization of the gobioid palatopterygoquadrate complex and its relevance to gobioid systematics. Journal of Natural History 23, 325-353. DOI 10.1080/00222938900770211

HoEse, D.F. 1983. Sensory papilla patterns of the cheek lateralis system in the gobioid fishes Acentrogobius and Glossogobius, and their significance for the classification of gobioid fishes. Records of the Australian Museum 35, 223-229.

DOI 10.3853/j.0067-1975.35.1983.319

HoEse, D.F. 1984. Gobioidei: relationships, 588-591. In Moser, H.G., Richards, W.J., Cohen, D.M., Fahay, M.P., Kendall, A.W. JR. \& RichaRDSON, S.L. (eds) Ontogeny and systematics of fishes. American Society of Ichthyologists and Herpetologists, Special Publication 1.

Hoese, D.F. \& GILl, A.C. 1993. Phylogenetic relationships of eleotridid fishes (Perciformes, Gobioidei). Bulletin of Marine Science 52, 395-414.

Johnson, G.D. \& Brothers, E.B. 1993. Schindleria: a paedomorphic goby (Teleostei: Gobioidei). Bulletin of Marine Science 52, 441-471.

JoRDAN, D.S. \& EvERMANN, B.W. 1896. Fishes of North and Middle America: a descriptive catalogue of the species of fish-like vertebrates found in waters of North America north of Isthmus of Panama. Part I. Bulletin of the United States National Museum 47, 1-1240.

LACHNER, E.A. \& KARNELla, S.L. 1980. Fishes of the Indo-Pacific genus Eviota with descriptions of eight new species (Teleostei: Gobiidae). Smithsonian Contributions to Zoology 315, 1-127. DOI 10.5479/si.00810282.315

Marzluff, J.M. \& Dial, K.P. 1991. Life history correlates of taxonomic diversity. Ecology 72, 428-439. DOI 10.2307/2937185

MilleR, P.J. 1973. The osteology and adaptive features of Rhyacichthys aspro (Teleostei: Gobioidei) and the classification of gobioid fishes. Journal of Zoology, London 171, 397-434. DOI 10.1111/j.1469-7998.1973.tb05347.x

MilLER, P.J. 1979. Adaptiveness and implications of small size in teleosts. Symposium of the Zoological Society of London 44, 263-306.

Monod, T. 1968. Le complexe urophore des poissons téléostéens. Mémoires de l'Institut Fondamental d'Afrique Noire 81, $1-705$.

MunDAY, P.L. \& JONES, G.P. 1998. The ecological implications of small body size among coral-reef fishes. Oceanography and Marine Biology: an Annual Review 36, 373-411.

Near, T.J., Dornburg, A., Eytan, R.I., Keck, B.P., Smith, W.L., Kuhn, K.L., Moore, J.A., Price, S.A., Burbrink, F.T., FriedMan, M. \& Wainwright, P.C. 2013. Phylogeny and tempo of diversification of spiny-rayed fishes. Proceedings of the $\mathrm{Na}$ tional Academy of Sciences of the United States of America 101, 12738-12743. DOI 10.1073/pnas.1304661110 
Nelson, J.S. 2006. Fishes of the World. Fourth Edition. 601 pp. John Wiley \& Sons, Hoboken.

Nolf, D., Rana, R.S. \& Singh, H. 2006. Fish otoliths from the Ypresian (early Eocene) of Vastan, Gujarat, India. Bulletin de l'Institut Royal des Sciences Naturelles de Belgique, Sciences de la Terre 76, 105-118.

OBrhelovÁ, N. 1961. Vergleichende Osteologie der tertiären Süsswasserfische Böhmens (Gobioidei). Sborník Ústředního ústavu geologického, Oddíl paleontologický 26, 103-192.

Papazzoni, C.A., Carnevale, G., Fornaciari, E., Giusberti, L. \& Trevisani, E. 2014. The Pesciara-Monte Postale FossilLagerstätte: 1. Biostratigraphy, sedimentology and depositional model, 29-36. In Papazzoni, C.A., Giusberti, L., Carnevale, G., Roghi, G., Bassi, D. \& Zorzin, R. (eds) The Bolca Fossil-Lagerstätten: A window into the Eocene World. Rendiconti della Società Paleontologica Italiana 4.

Patterson, C. 1993. An overview of the early fossil record of acanthomorphs. Bulletin of Marine Science 52, 29-59.

Patton, W.K. 1994. Distribution and ecology of animals associated with branching corals (Acropora spp.) from the Great Barrier Reef, Australia. Bulletin of Marine Science 55, 193-211.

Pezold, F. 1993. Evidence for a monophyletic Gobiinae. Copeia 1993, 634-643. DOI 10.2307/1447224

PřikrYL, T. 2014. A new species of the sleeper goby (Gobioidei, Eleotridae) from the České Středohoří Mountains (Czech Republic, Oligocene) and analysis of the validity of the family Pirskeniidae. Paläontologische Zeitschrift 88, 187-196. DOI 10.1007/s12542-013-0188-y

Punekar, J. \& Saraswati, P.K. 2010. Age of the Vastan Lignite in context of some oldest Cenozoic fossil mammals from India. Journal of the Geological Society of India 76, 63-68. DOI 10.1007/s12594-010-0076-y

Randall, J.E., Allen, G.R. \& Steene, R.C. 1997. Fishes of the Great Barrier Reef and Coral Sea. 557 pp. Crawford House Publishing, Bathurst.

REGAN, C.T. 1911. The osteology and classification of the gobioid fishes. Annals and Magazine of Natural History, Series 8 8(48), 729-733. DOI 10.1080/00222931108693090

SANZO, L. 1911. Distribuzione delle papille cutanee (organi ciatiformi) e suo valore sistematico nei Gobi. Mitteilungen aus der Zoologischen Station zu Neapel 20, 249-328.

SCHOENER, T.W. 1974. Resource partitioning in ecological communities. Science 185, 27-39.

DOI 10.1126/science.185.4145.27

SPRINGER, V.G. 1983. Tyson belos, new genus and species of western Pacific fish (Gobiidae, Xenisthminae), with discussion of gobioid osteology and classification. Smithsonian Contributions to Zoology 390, 1-40.

DOI 10.5479/si.00810282.390

SPRINGER, V.G. 1988. Rotuma lewisi, new genus and species of fish from the southwest Pacific (Gobioidei, Xenisthmidae). Proceedings of the Biological Society of Washington 101, $530-539$.

Thacker, C.E. 2009. Phylogeny of Gobioidei and placement within Acanthomorpha, with a new classification and investigation of diversification and character evolution. Copeia 2009, 93-104. DOI 10.1643/CI-08-004

TYLER, J.C. 1971. Habitat preferences of the fishes that dwell in shrub corals on the Great Barrier Reef. Proceedings of the Academy of Natural Sciences of Philadelphia 123, 1-26.

Tyler, J.C. \& BöHLKE, J.E. 1972. Records of sponge dwelling fishes, primarily of the Caribbean. Bulletin of Marine Science 22, 601-642.

Volta, G.S. 1796. Ittiolitologia Veronese del Museo Bozziano ora annesso a quello del Conte Giovambattista Gazola e di altri gabinetti di fossili veronesi. 323 pp. Stamperia Giuliani, Verona.

WERNER, E.E. 1984. The mechanisms of species interactions and community organisation in fish, 360-382. In Strong, D.R. (ed.) Ecological communities. Princeton University Press, Princeton.

WiLEY, E.O. \& JohnSON, G.D. 2010. A teleost classification based on monophyletic groups, 123-182. In NeLson, J.S., SchultZe, H.-P. \& WILSON, M.V.H. (eds) Origin and Phylogenetic Interrelationships of Teleosts. Verlag Dr. Friedrich Pfeil, München.

Winterbottom, R. 1990. The Trimmatom nanus species complex (Actinopterygii, Gobiidae): Phylogeny and progenetic heterochrony. Systematic Zoology 39, 253-265. DOI 10.2307/2992185

Winterbottom, R. 1993. Search for the gobioid sister group (Actinopterygii: Percomorpha). Bulletin of Marine Science 52, 395-414.

Winterbottom, R. \& Emery, A.R. 1981. A new genus and two new species of gobiid fishes (Perciformes) from the Chagos Archipelago, Central Indian Ocean. Environmental Biology of Fishes 6, 139-149. DOI 10.1007/BF00002777

Woodward, A.S. 1901. Catalogue of the fossil fishes in the British Museum (Natural History). Volume IV. 638 pp. British Museum (Natural History), London. 